\title{
水蒸気により駆動する水ピストンエンジンの駆動条件に関する検討 A Study on Operation Condition of Steam-Driven Water-Piston Engine
}

\author{
胡 涛（名大院） ○ 内田 正宏（名大）百瀬 豊（百瀨機械設計） \\ 正 北川 邦行（名大）正 長谷川 達也（名大）
}

Tao HU' ${ }^{1}$, Masahiro UCHIDA', Yutaka MOMOSE ${ }^{2}$, Kuniyuki KITAGAWA' and Tatsuya HASEGAWA ${ }^{1}$

1. Nagoya University, Furo-cho 1, Chikusa-ku, Nagoya

2. Momose Mechanical Design CO., LTD., Nihongishinmachi, Anjo

\begin{abstract}
In the present study, a water-piston engine driven by the low temperature waste heat is developed and numerical simulations and experiments are conducted to establish the steady operating condition. Both numerical and experimental results show that present experimental apparatus is not capable to attain the steady oscillation state. However, these results show the importance of the appropriate balance between the amount of supplied steam and condensed water in water-piston engine. Additioionally, numerical results and experimental results demonstrate the availability of intermittent steam supply equipment and upper vertical tube cooling devices, respectively. Hence, the experimental apparatus will be improved based on present results in the future.
\end{abstract}

Key Words: Steam, Waste heat, Condensation, Engine

\section{1.はじめに}

各種熱機関から排出される低温排熱は莫大な量になるた め，再利用を促進すればエネルギ一資源の有効利用の点で 大きな意味を持つことになる。しかし，これらの排熱の温 度は通常 $200^{\circ} \mathrm{C}$ 以下であり，エネルギー密度が小さいこと から，効率的な利用が難しい，そこで本研究では，このよ うな低質排熱を利用する機関として，排熱で作り出した水 蒸気の膨張・凝縮により駆動する水ピストンエンジンを考 案した。ここでは，水ピストンエンジンの動作特性を調べ るために行ったモデルシミュレーションと実験の結果につ いて報告する。

\section{2. 水ピストンエンジン}

水ピストンエンジンの動作原理について図 1 に示す。ま ず，垂直に立てられた円管内を水で満たし，そこに上面か ら水蒸気を流入させる．流入した水蒸気によって水面は下 に押し下げられるが, 膨張した水蒸気は温度が下がるため 蒸気室内で凝縮が起こる。この凝縮の効果によって蒝気室 内は負圧となり水面が上昇するが，蒸気の連続的な流入の ため水面はある程度まで上昇するとまた降下する。このよ うな動作を繰り返して，水ピストンエンジンは連続的に動 作する.

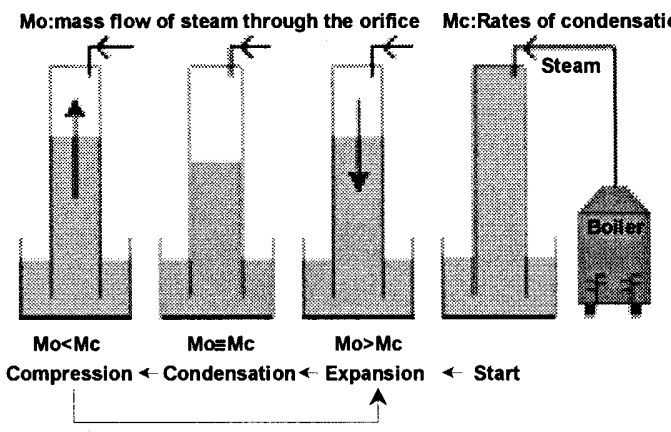

Fig.1 Outline of water-pis ton engine

\section{3. 数値計算}

計算モデルの概略を図 2 に示す。このモデルの支配方程 式を以下に示す.

水柱の一次元運動方程式 :

$\rho \frac{\pi}{4} D^{2}\left(H_{w}+h\right) \frac{d^{2} h}{d t^{2}}=\frac{\pi}{4} D^{2}\left(P_{o}-p\right)-\frac{\pi}{4} D^{2} \rho g h-\eta\left|\frac{d h}{d t}\right|$

蒸気室のエネルギー保存式 :

$\frac{d Q}{d t}-L m_{c}-\frac{\pi}{4} D^{2} \kappa\left(T-T_{s}\right)=p \frac{d V}{d t}+m C v \frac{d T}{d t}$

第 2 式左辺の第 1 項はオリフィスから供給される水蒸気の エネルギーを表し，この流入量はオリフィス関係式 ${ }^{(1)}$ に従 って決定される. また, 第 2 項は水蒸気の凝縮・蒸発に伴 う潜熱の効果を表し，凝縮量については大西らの式 ${ }^{(2)} に よ$ り計算した。 また, 第 3 項は蒸気から液柱表面への熱伝達 による影響を表す。これらの式に質量の保存式及び状態方 程式を加えた支配方程式により，水ピストンエンジンの動 作を記述した。

水ピストンエンジンの諸元については次の通りに設定し た. $\mathrm{Hv}=1[\mathrm{~m}], \mathrm{Hw}=0.2[\mathrm{~m}], \mathrm{D}=70[\mathrm{~mm}]$, オリフィス径 $1[\mathrm{~mm}]$ とし, 蒸気供給ボイラについては圧力 0.15 [MPa], 蒸気温 度 $473[\mathrm{~K}]$ とした。また，初期条件としては $\mathrm{h}=0.8[\mathrm{~m}]$, $\mathrm{p}=0.14[\mathrm{MPa}], \mathrm{T}=300[\mathrm{~K}]$ とした.

図 3(a)扩よび(b)に，それぞれ連続的に蒸気の供給を行 った場合と間欠的に蒸気が供給されるように設定した場合 の，水柱高さの時間変化を示す. 図 $3(\mathrm{a})$ から解るように, 連続的に蒸気の供給を行うと, 時間とともに水柱の高さは 減少し，同時に振幅も小さくなるという結果が得られた. これは蒸気を連続的に供給した場合には，1 サイクルの間 に供給される蒸気量が 管内で凝縮する蒸気量 よりも多く, 時間経過と 共に管内压力が高くな って水柱を下に押し下 げるためである。このこ とから安定な動作を得 るためには，供給される 蒸気量と凝縮する蒸気 量が釣り合うことが重 要と考え, 蒸気の流入部 にバルブを付けて流入 量と流入タイミングを

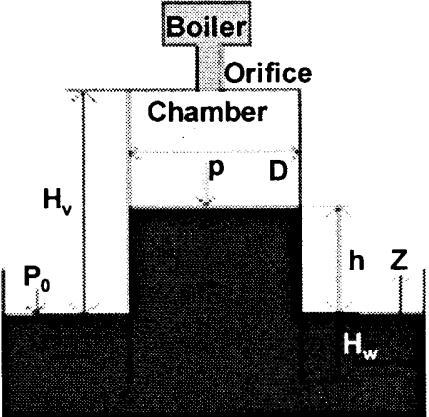

Fig.2 Numerical model 


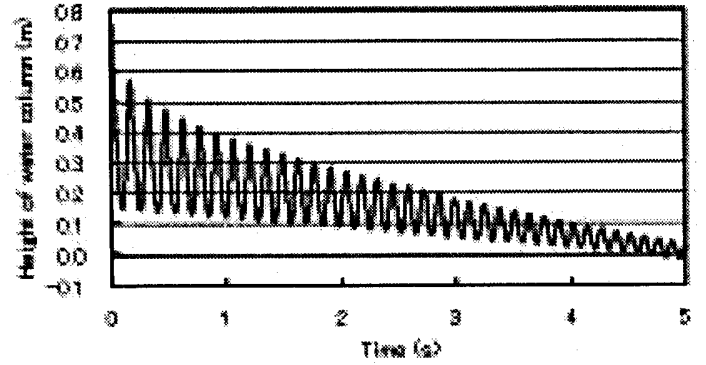

(a) Continuous steam supplying case

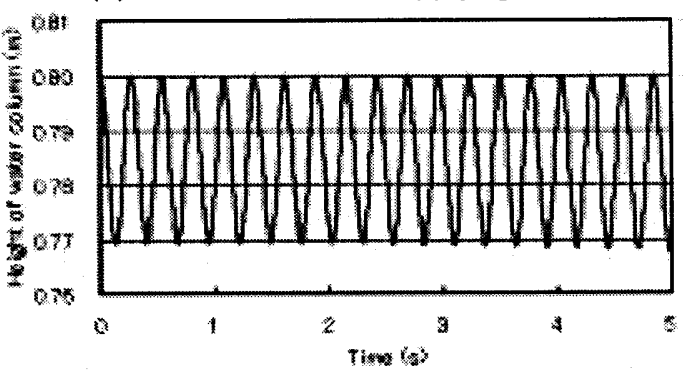

(b) Intermittentsteam supplying case

Fig.3 Numerical results

制御する機構を考えた。ここでは蒸気流入を液柱高さが 0.8 [m] を超えたときだけに制限し，それ以外の時はバルブ を閉じた．その結果，図 3(b)に示すように，バルブを付け て蒸気流入を制御した場合には，ピストン運動が安定する 結果が得られた.すなわち, 蒸気流入を制御した場合には, ピストンのストロークが大きくなり，熱エネルギーを効率 的に運動エネルギーに変換できることが示された。

\section{4. 実験}

実験装置の概略を図 4 に示す。下部の管は水槽に固定さ れており，その中に垂直に管を立て，棒でディスクと接続 する．上部の管内で水柱の振動が起こると，管自体も上下 運動し，棒で接続されたディスクの回転を通して運動は電

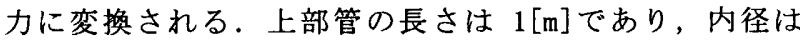
$70[\mathrm{~mm}]$ である. また, 水蒸気は $1.6[\mathrm{~kW}]$ の電気ヒーターを 備えるボイラで生成し, $3[\mathrm{~mm}]$ のオリフィスを通して上部管 内へ供給される。

図 5 に実験で得られた出力電流の時間変化を示す．この 装置による実験では，上部管の往復運動のストロークは約 $20[\mathrm{~mm}]$ であり，これはディスクを一方向に回転させるには

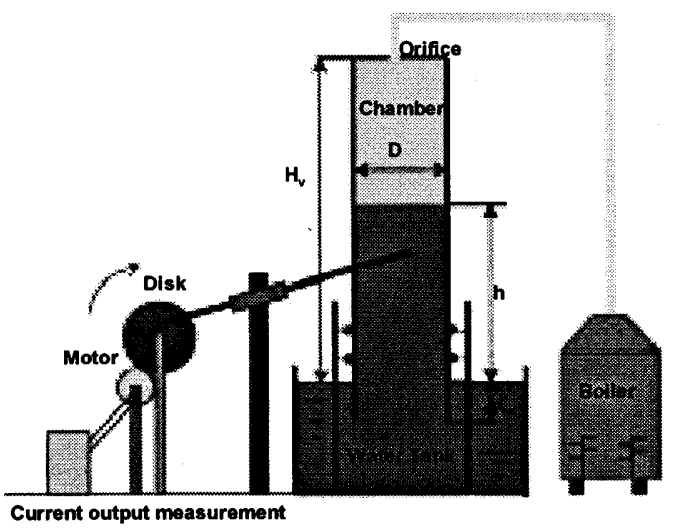

Fig.4 Experimental apparatus
不十分なため, ディスクは前後に往復運動をする. 出力電 流が正と負の值を交互にとるのは,このような理由による. また, ピストンの往復運動のストロークは時間とともに減 衰している。これは数值計算において振動が減衰した理由 と同じく蒸気の供給量が多すぎるためと考えられる．ここ で，蒸気の供給量と凝縮量のバランスをとるために，計算 結果が示すように蒸気流入を制御する装置を用いる方法が あるが装置の改造が必要なことから，先に簡単な方法で蒸 気流入量と凝縮量のバランスを変化させ, 効果を確認する ことにした。ここでは上部管壁をアイスバックで冷却し， 同時に水槽内に氷を入れることで凝縮量の増大を図り，実 験を行った.この冷却ありの場合の実験結果を図 6 に示す. この実験の場合には, 振幅の減衰は小さく, 45 分間安定し た動作が得られた. 更に, 図 5 との比較から解るように振 幅が大きくなっていることが解る．冷却により凝縮の促進 を図った実験からも，水蒸気の供給量と凝縮量のバランス が動作に重要な役割を果たしていることが示された。

\section{5.まとめ}

低温排熱を利用する水ピストンエンジンのシミュレーシ ヨンと実験を行い, 水蒸気の供給量と凝縮量のバランスが 安定な運動状態を得るのに重要なことが示された。また, バランスを変化させるのに蒸気流入の制御とピストン壁の 冷却が有効であることが示された．今後，更に検討をして 装置を改良していく。

\section{参考文献}

(1) R. Jyh-Chyang and H. Chih-Hung, Tribology International, 37, pp. 309-315 (2004).

(2) Y. Ohnishi and Y. Sone, J. Phys. Soc. Japan, 47, pp. 1676-1685, (1979).

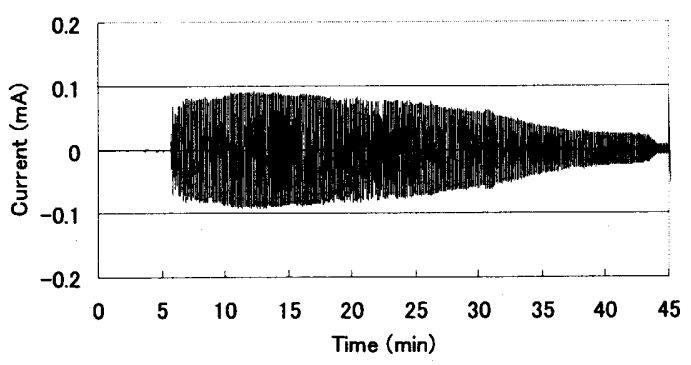

Fig.5 Experiment without cooling

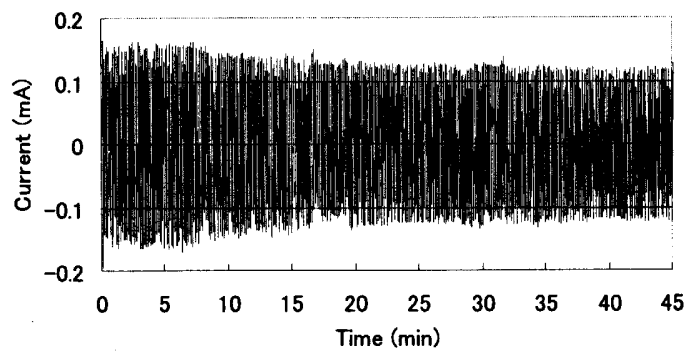

Fig.6 Experiment with cooling 